Online | 4-8 May 2020

\title{
Potential Effect of Halogens on Atmospheric Oxidation and Air Quality in China
}

Qinyi Li , Alba Badia1, Tao Wang², Golam Sarwar³, Xiao Fu², Li Zhang4,5, Qiang Zhang6, Jimmy Fung7, Carlos A. Cuevas' ${ }^{1}$, Shanshan Wang ${ }^{8}$, Bin Zhou ${ }^{8}$, and Alfonso Saiz-Lopez ${ }^{1,8, *}$

1Department of Atmospheric Chemistry and Climate, Institute of Physical Chemistry Rocasolano, CSIC, Madrid 28006, Spain 2Department of Civil and Environmental Engineering, The Hong Kong Polytechnic University, Hong Kong, China ${ }^{3}$ National Exposure Research Laboratory, Environmental Protection Agency, Research Triangle Park, NC 27711, USA ${ }^{4}$ Atmospheric and Oceanic Sciences, Princeton University, Princeton, NJ 08540, USA

${ }_{5}^{5}$ Geophysical Fluid Dynamics Laboratory, National Oceanic and Atmospheric Administration, Princeton, NJ 08544,USA ${ }^{6}$ Department of Earth System Science, Tsinghua University, Beijing 100084, China 7Division of Environment and Sustainability, Hong Kong University of Science and Technology, Hong Kong, China ${ }^{8}$ Department of Environmental Science and Engineering, Fudan University, Shanghai 200433, China 


\section{O N T E N T S}

\section{Introduction}

1.1 Background

1.2 Motivation

\section{Method}

2.1 WRF-Chem model

2.2 Data

2.3 Simulation setup

\section{Results and Discussion}

3.1 Simulated halogens

3.2 Halogen impact on individual oxidants

3.3 Halogen impact on atmospheric oxidation capacity

3.4 Connection of halogen effect and $\mathrm{O}_{3}$ regime

\section{Conclusion}

4.1 Summary

4.2 Implication 


\section{Background}

Degraded air quality has become one of the dominant worldwide causes of mortality, with 3.3 million premature deaths each year in the world and 1.3 million in China. (Lelieveld et al., 2015)

\section{Emission}

- Anthropogenic source

- Natural source (land)

- Natural source(ocean)

\section{Meteorology}

- Wind

- Turbulence

- Radiation

- Temperature

- Humidity

Oxidation process

(less reported)

- $\mathrm{OH}$

- $\mathrm{HO}_{2}$

- $\mathrm{O}_{3}$

- $\mathrm{NO}_{3}$

- $\mathrm{Cl}$ 


\section{Motivation}

\section{- Air pollution in China}

$>$ Reduced emission of primary air pollutants (Zheng et al., 2018).

$>$ Increased level of ambient secondary air pollutants (Li K et al., 2019).

$>$ Raised attention of oxidation capacity.

\section{- Potential significant effects of halogens}

Large control of reactive halogens $(\mathrm{Cl}, \mathrm{Br}$, and I) on oxidants in marine boundary layer (Saiz-Lopez \& von Glasow, 2012).

$>$ Noticeable emission of halogens in mainland China and along the coast.

$>$ No report of overall halogen impact on oxidation capacity and air quality in China.

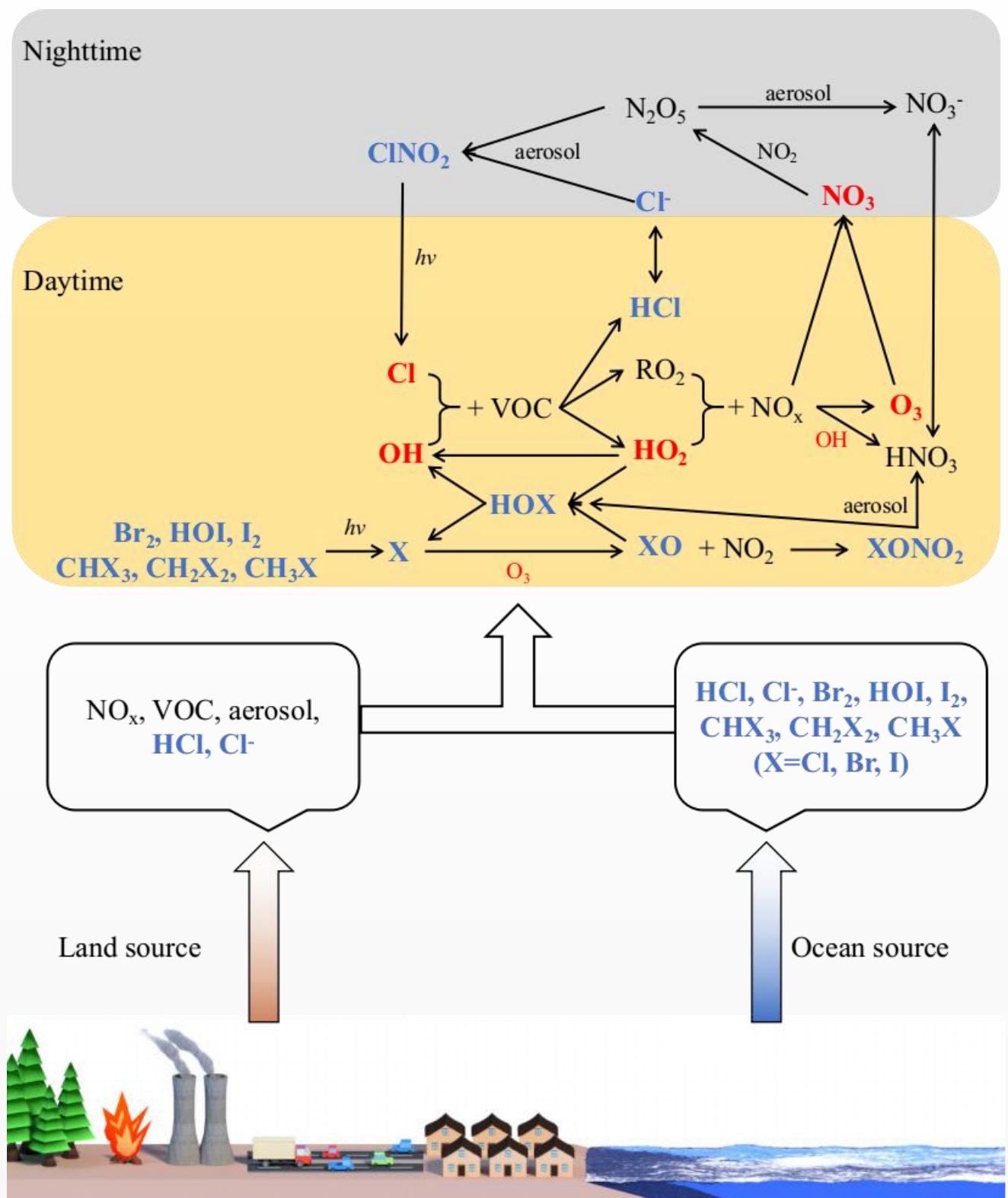




\section{Method}

\section{WRF-Chem model}

- Grell et al., 2005.

- Badia et al. (2019) implemented comprehensive reactive halogen sources and chemistry.

- Heterogeneous production of HONO on aerosol and ground surface was also implemented in this work following Zhang et al. (2017).

\section{Data}

- Emission: routine air pollutants (MEIC, meicmodel.org), anthropogenic chlorine (Fu et al., 2018), oceanic halogen (Badia et al., 2019), fire emission (FINN, Wiedinmyer et al., 2011).

- Air pollutant data: $\mathrm{O}_{3}(\mathrm{MEE}$, www.mee.gov.cn/hjzl/dqhj/qgkqzlssfb ).

- Meteorological data: NCEP datasets, including ds083.2, ds351.0, and ds461.0.

\section{Simulation setup}

- Simulations were conducted for each month in 2018 with a spin up of ten days.

- Five scenarios were designed. Only BASE and HAL are presented here. Changes in atmospheric compositions between BASE and HAL represent the impact of the overall halogen sources and chemistry.

\begin{tabular}{c|ccccc}
\hline Cases & $\begin{array}{c}\text { Anthropogenic } \\
\text { chlorine } \\
\text { emission }\end{array}$ & $\begin{array}{c}\text { Oceanic } \\
\text { halogen } \\
\text { emission }\end{array}$ & $\begin{array}{c}\text { Chlorine } \\
\text { chemistry }\end{array}$ & $\begin{array}{c}\text { Bromine } \\
\text { chemistry }\end{array}$ & $\begin{array}{c}\text { Iodine } \\
\text { chemistry }\end{array}$ \\
\hline BASE & No & No & No & No & No \\
HAL & Yes & Yes & Yes & Yes & Yes \\
OCN & No & Yes & Yes & Yes & Yes \\
CHL & Yes & Yes & Yes & No & No \\
CHL+BRM & Yes & Yes & Yes & Yes & No \\
\hline
\end{tabular}




\section{Simulated halogens}

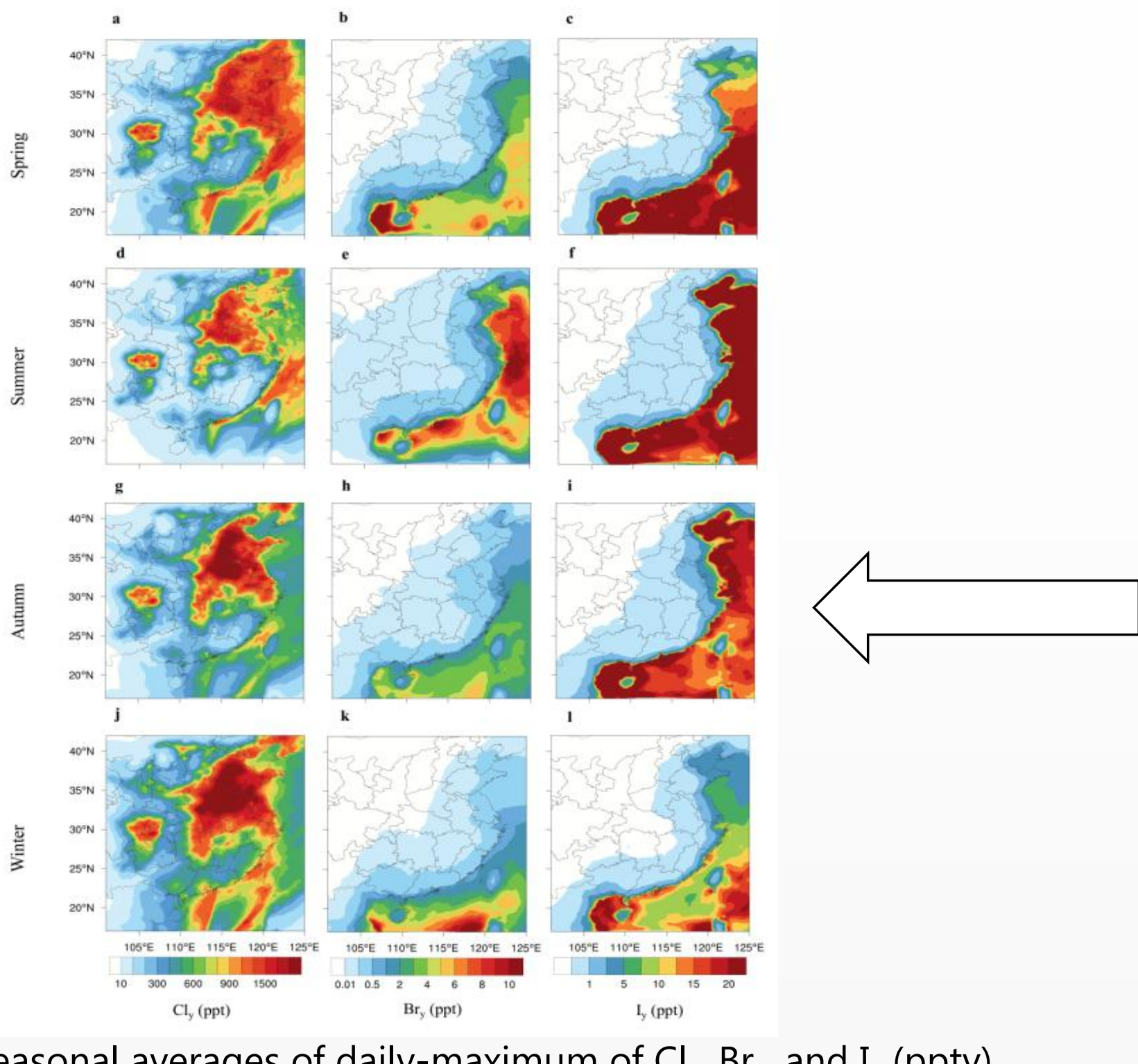

Seasonal averages of daily-maximum of $\mathrm{Cl}_{\mathrm{y}}, \mathrm{Br}_{\mathrm{y}}$, and $\mathrm{I}_{\mathrm{y}}$ (pptv) at the surface in the HAL scenario.

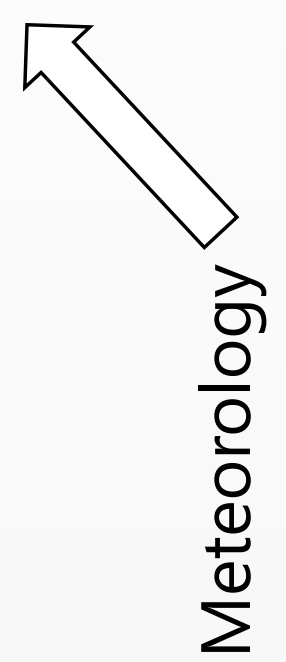

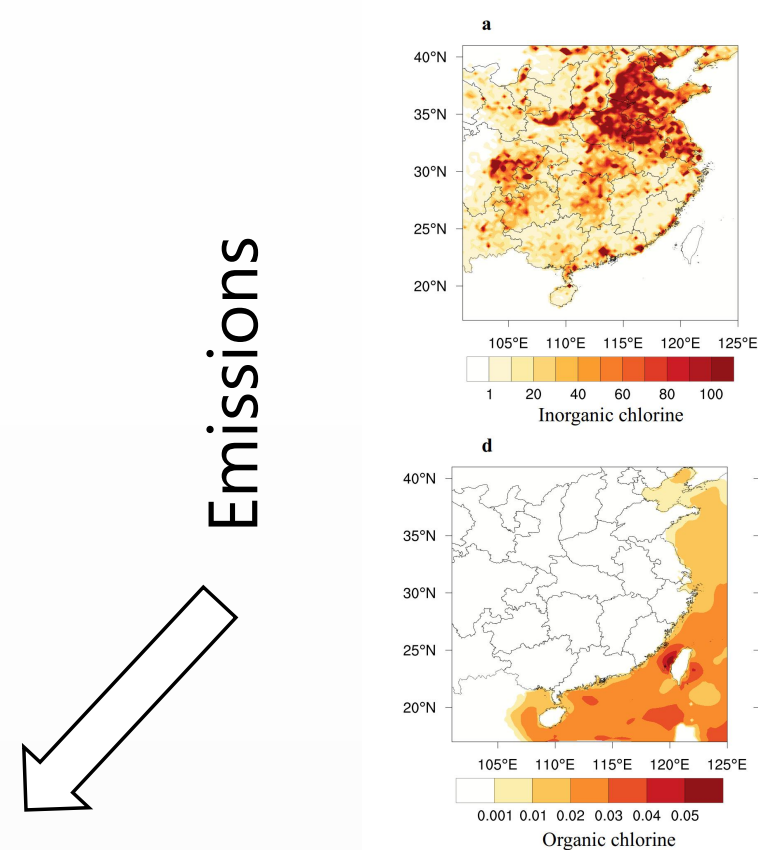
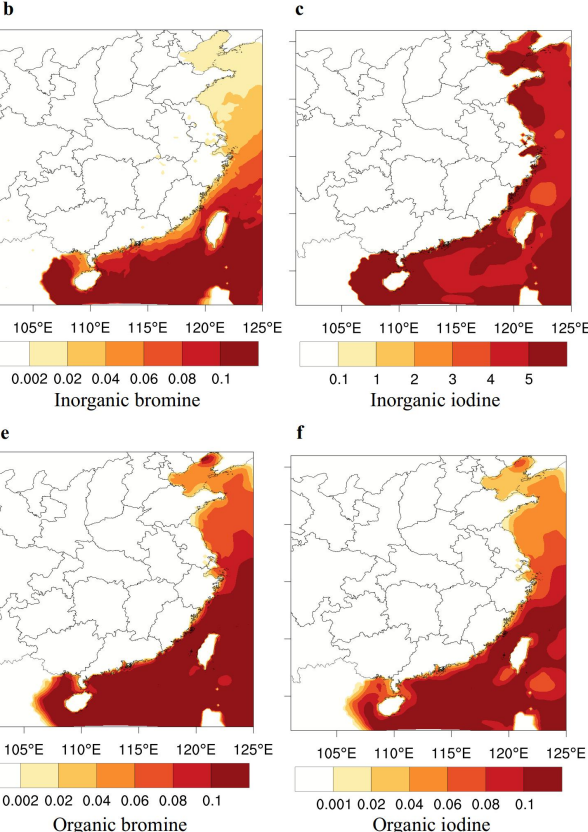

Annual average emissions (multiplied by 1013) of $\mathrm{Cl}, \mathrm{Br}$, and I species $\left(\mathrm{kg} \mathrm{m}^{-2} \mathrm{~s}^{-1}\right)$.
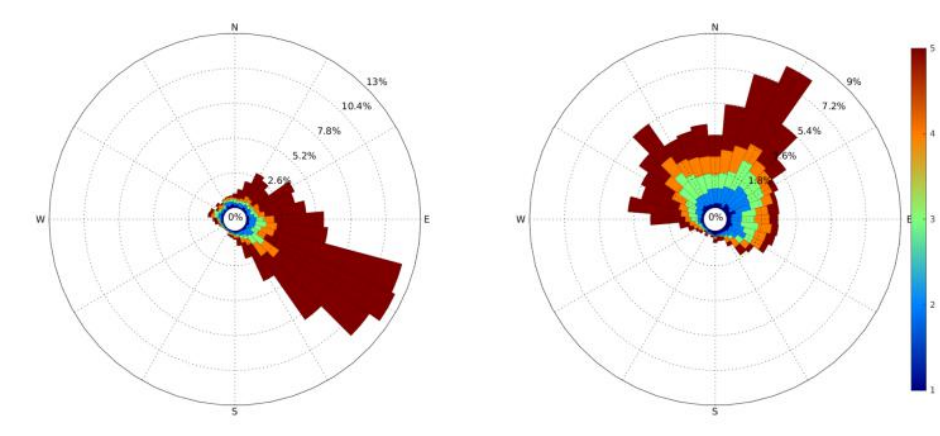

Wind rose in summer

Wind rose in winter 


\section{Halogen impact on oxidants}

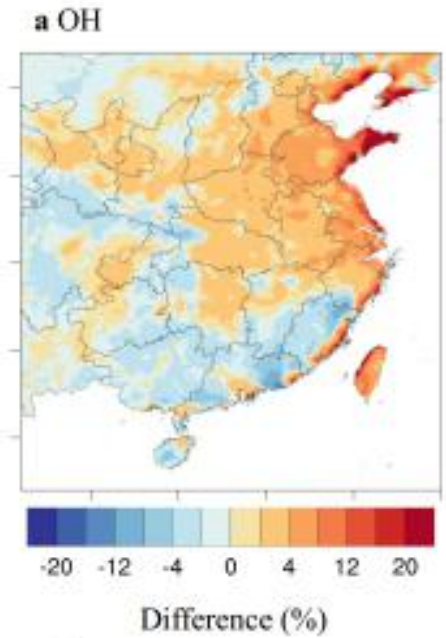

c $\mathrm{O}_{3}$

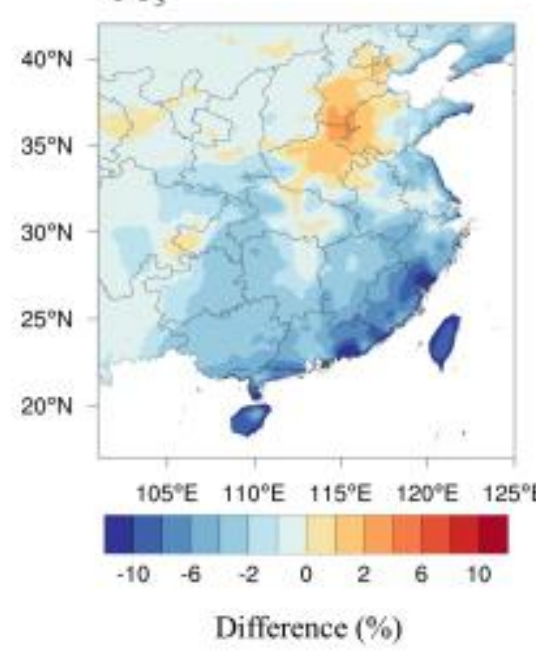

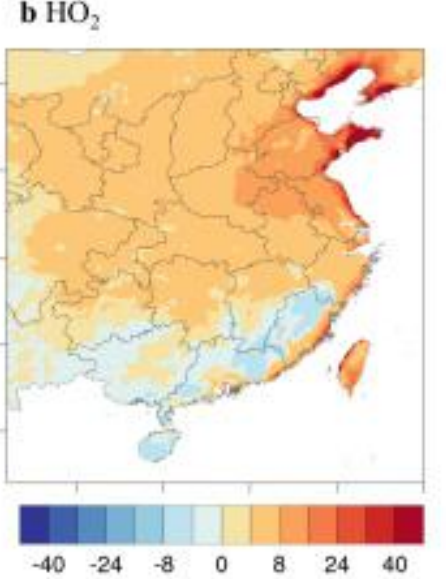

Difference (\%)

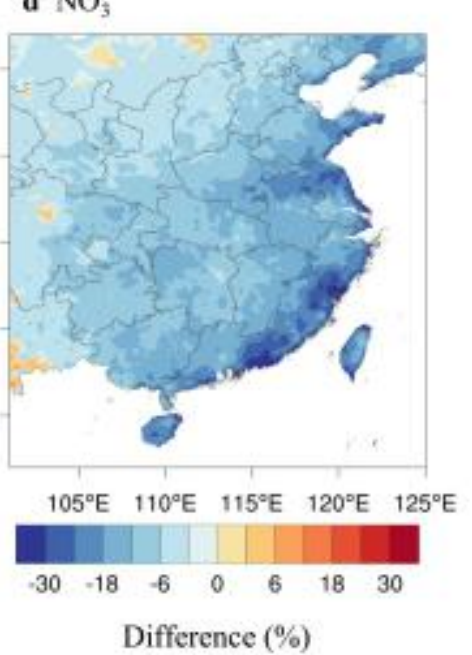

Annual average impact of halogen chemistry on the level of atmospheric oxidants $\left(\mathrm{OH}, \mathrm{HO}_{2}, \mathrm{O}_{3}\right.$, and $\left.\mathrm{NO}_{3}\right)$ at the surface in China.

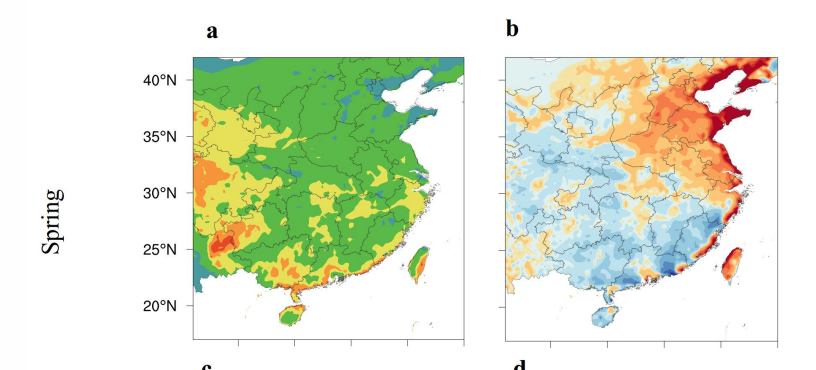

${ }^{40 \mathrm{~N}}$
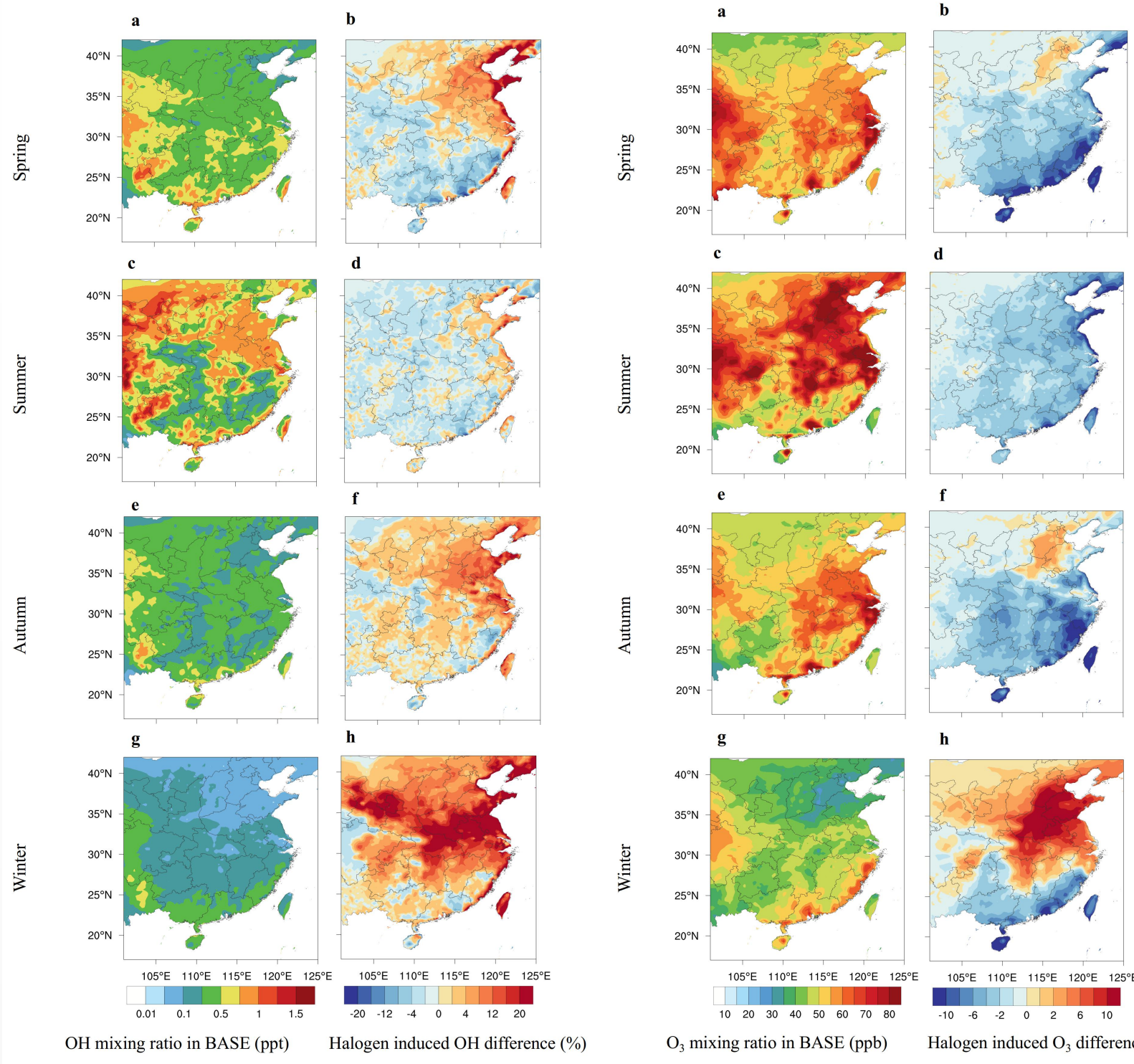

Seasonal average for $\mathrm{OH}$
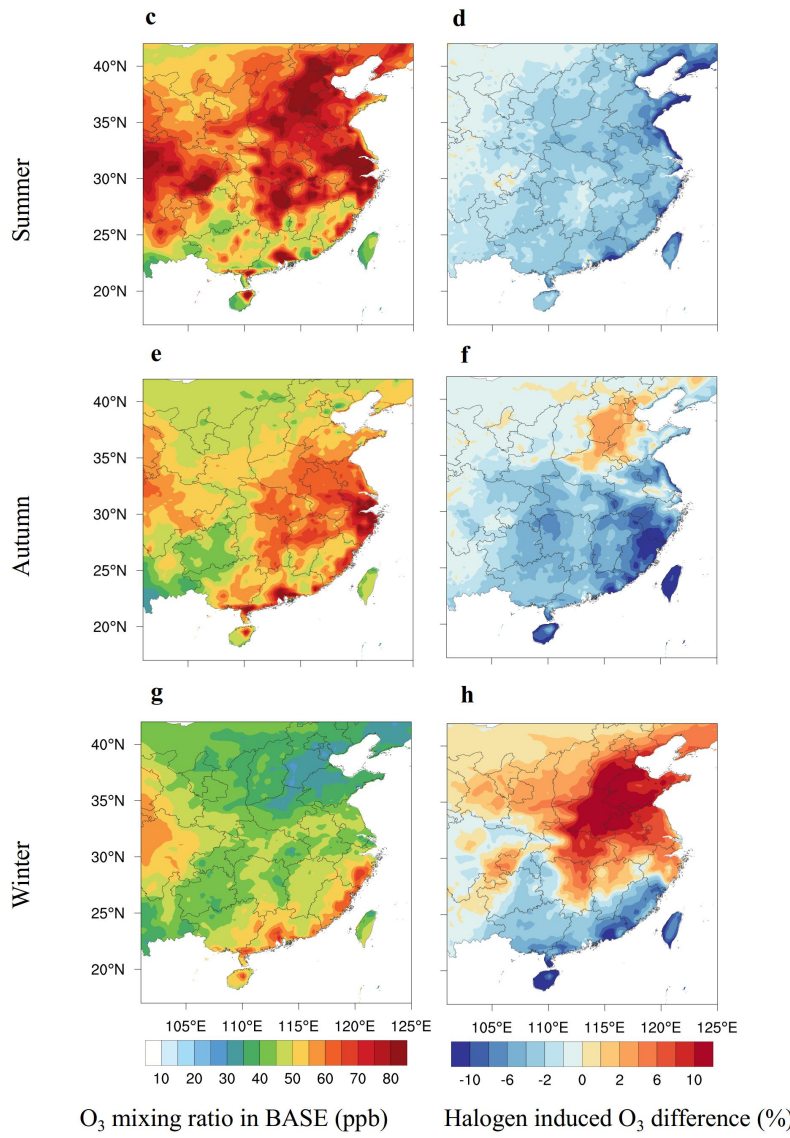

Seasonal average for $\mathrm{O}_{3}$ 


\section{Halogen impact on Atmospheric Oxidation Capacity (HAOC)}

AOC is a unified metric combining all oxidants, $\mathrm{OH}, \mathrm{O}_{3}, \mathrm{NO}_{3}$, and $\mathrm{Cl}$, their reactants, and rates of reactions (Calculation is attached at the end of this file). HAOC is the halogen impact on AOC.

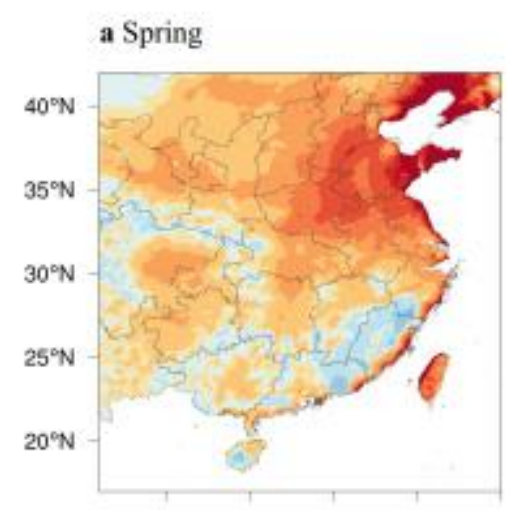

b Summer

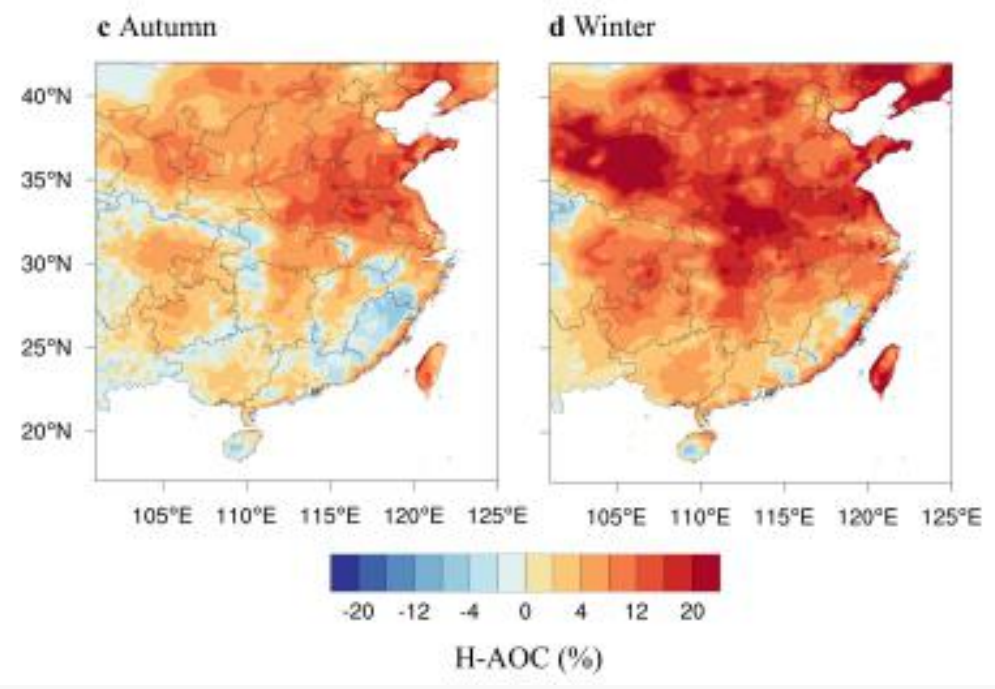

HAOC at the surface in China.
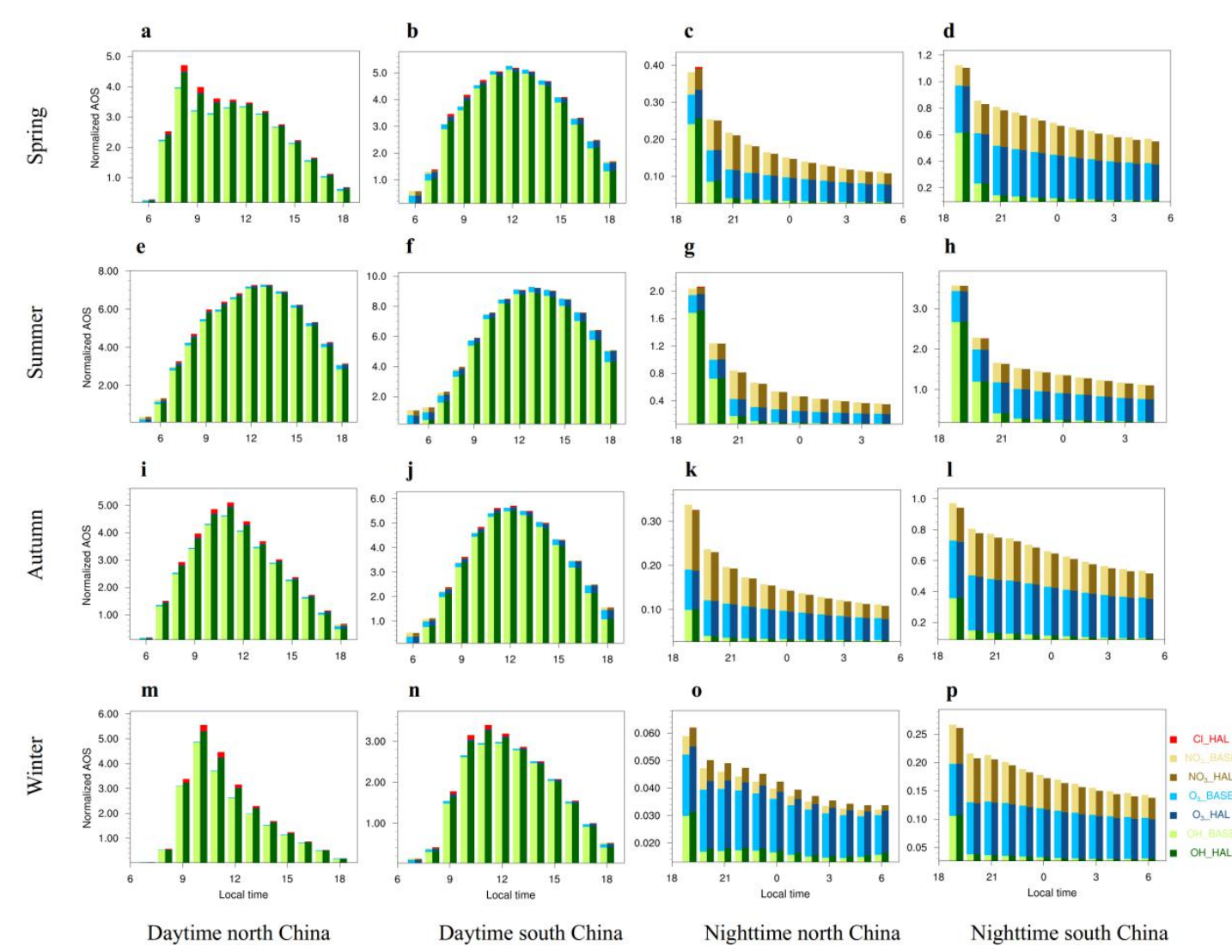

Daytime and nighttime hourly variations of $A O C$ at the surface in north and south China in four seasons. AOC is normalised by dividing

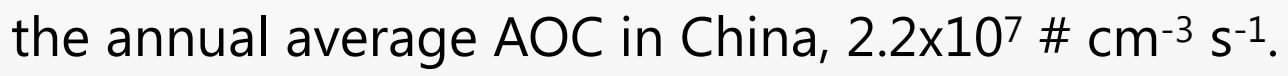




\section{Connection of $\mathrm{HAOC}$ and $\mathrm{O}_{3}$ formation regime}

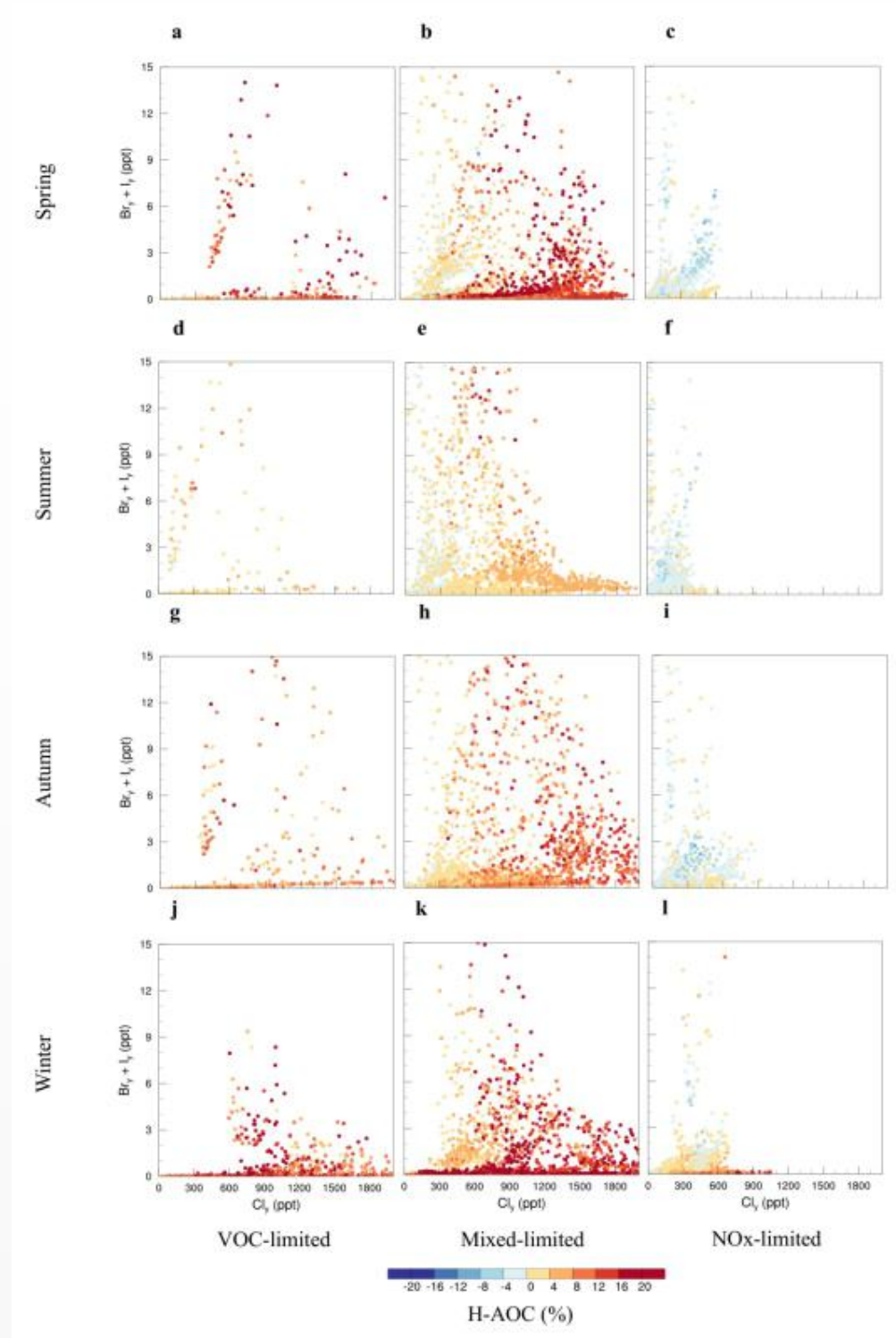

- $\mathrm{HAOC}$ is closely related to the $\mathrm{O}_{3}$ formation chemical regime.

- In VOC-limited regions, HAOC shows an increase pattern in all seasons;

- In mixed-limited regions, $\mathrm{HAOC}$ is significantly increased when $\mathrm{Cl}_{\mathrm{y}}$ is over 600 pptv (typical value over polluted China) or when $\mathrm{Br}_{\mathrm{y}}+\mathrm{I}_{\mathrm{y}}$ levels are negligible, and is near zero or decreased when $\mathrm{Cl}_{y}$ is lower than $600 \mathrm{pptv}$;

- In $\mathrm{NO}_{\mathrm{x}}$-limited regions, $\mathrm{HAOC}$ is generally decreased except in winter, when the levels of bromine and iodine species are negligible in mainland China.

- A dynamic strategy is required to curb the enhancement effect of halogens on $\mathrm{AOC}$ under various $\mathrm{O}_{3}$ regimes.

Dependence of $\mathrm{HAOC}$ on the levels of halogen species under different $\mathrm{O}_{3}$ formation regimes in four seasons. 


\section{Conclusion and implication}

* Highlights:

- First assessment of halogen impact on atmospheric oxidation and air quality over China.

- Halogens result in enhanced oxidation throughout the year in polluted regions in China.

- Large spatio-temporal heterogeneity of the halogen-mediated effect on oxidation capacity, which can be explained by the Asian monsoon, the location and intensity of halogen sources, and the ozone formation regime.

Implication:

- Halogens potentially contributes to close the gap between the observation and simulation of atmospheric oxidation in China.

- Current study implies a gap in our understanding of air pollution in China and a potential bias in policy design.

- Halogens affect China's air pollution exports to other parts of the world.

- A similar large influence is also expected in other regions with similar air quality issues and halogen emissions from anthropogenic and oceanic sources.

- The emission of halogens is expected to increase as a result of the projected natural phenomena (Iglesias-Suarez et al., 2020) and anthropogenic activity (Fang et al., 2019; Young et al., 2013) which warrants further investigation of the influence of halogen compounds on future atmospheric oxidation. 


\section{Acknowledgement}

\section{$¥ € \$ \quad$ Financial support}

$\checkmark$ European Research Council Executive Agency under the European Union's Horizon 2020 Research and Innovation Programme (Project ERC-2016- COG 726349 CLIMAHAL).

$\checkmark$ Consejo Superior de Investigaciones Científicas (CSIC) of Spain.

$\checkmark$ The Program for Professor of Special Appointment (Eastern Scholar) at Shanghai Institutions of Higher Learning and Shanghai Thousand Talents Program.

$\checkmark$ National Natural Science Foundation of China (41775113) - Fudan team.

$\checkmark$ Hong Kong Research Grants Council (A-PolyU502/16, T24-504/17-N) - HKPU team.

\section{$\bigcirc$ Computation support}

$\checkmark$ Computing resources, support, and data storage were provided by the Climate Simulation Laboratory at NCAR's Computational and Information Systems Laboratory (CISL), sponsored by the NSF.

\section{Model support}

$\checkmark$ The development and maintenance of the WRF-Chem model are conducted by NOAA/ESRL/GSD in active collaboration with other institutes. 


\section{Reference}

Badia, A., Reeves, C. E., Baker, A. R., Saiz-Lopez, A., Volkamer, R., Koenig, T. K., et al. (2019). Importance of reactive halogens in the tropical marine atmosphere: a regional modelling study using WRF-Chem. Atmospheric Chemistry and Physics, 19(5), 3161-3189.

Fang, X., Park, S., Saito, T., Tunnicliffe, R., Ganesan, A. L., Rigby, M., et al. (2019). Rapid increase in ozone-depleting chloroform emissions from China. Nat. Geosci., 12, 89-93.

Fu, X., Wang, T., Wang, S., Zhang, L., Cai, S., Xing, J., \& Hao, J. (2018). Anthropogenic emissions of hydrogen chloride and fine particulate chloride in China. Environmental Science \& Technology, 52(3), 1644-1654.

Grell, G. A., Peckham, S. E., Schmitz, R., McKeen, S. A., Frost, G., Skamarock, W. C., \& Eder, B. (2005). Fully coupled "online" chemistry within the WRF model. Atmospheric Environment, 39(37), 6957-6975.

Iglesias-Suarez, F., Badia, A., Fernandez, R.P., Cuevas, C.A., Kinnison, D.E., Tilmes, S., Lamarque, J.F., Long, M.C., Hossaini, R. and Saiz-Lopez, A., 2020. Natural halogens buffer tropospheric ozone in a changing climate. Nature Climate Change, 10(2), pp.147-154.

Lelieveld, J., Evans, J. S., Fnais, M., Giannadaki, D., \& Pozzer, A. (2015). The contribution of outdoor air pollution sources to premature mortality on a global scale. Nature, 525(7569), 367.

Li, K., Jacob, D. J., Liao, H., Shen, L., Zhang, Q., \& Bates, K. H. (2019). Anthropogenic drivers of 2013-2017 trends in summer surface ozone in China. Proceedings of the National Academy of Sciences, 116(2), 422-427.

Saiz-Lopez, A., \& von Glasow, R. (2012). Reactive halogen chemistry in the troposphere. Chemical Society Reviews, 41(19), 6448-6472.

Wiedinmyer, C., Akagi, S. K., Yokelson, R. J., Emmons, L. K., Al-Saadi, J. A., Orlando, J. J., \& Soja, A. J. (2011). The Fire INventory from NCAR (FINN): A high resolution global model to estimate the emissions from open burning. Geoscientific Model Development, 4(3), 625.

Young, P. J., Archibald, A. T., Bowman, K. W., Lamarque, J. F., Naik, V., Stevenson, D. S., et al. (2013). Pre-industrial to end 21st century projections of tropospheric ozone from the Atmospheric Chemistry and Climate Model Intercomparison Project (ACCMIP). Atmospheric Chemistry and Physics, 13(4), 2063-2090.

Zhang, L., Li, Q. Y., Wang, T., Ahmadov, R., Zhang, Q., Li, M., \& Lv, M. Y. (2017). Combined impacts of nitrous acid and nitryl chloride on lowertropospheric ozone: new module development in WRF-Chem and application to China. Atmospheric chemistry and physics, 17 (16), $9733-9750$.

Zheng, B., Tong, D., Li, M., Liu, F., Hong, C., Geng, G., et al. (2018). Trends in China's anthropogenic emissions since 2010 as the consequence of clean air actions. Atmospheric Chemistry and Physics, 18(19), 14095-14111. 


\section{Supplementary materials}

$$
A O C=\sum_{i=1}^{m}\left(\left[O X_{i}\right] \times \sum_{j=1}^{n}\left(a_{j} \times\left[C_{j}\right] \times k_{i, j}\right)\right)
$$

$\mathrm{m}$ and $\mathrm{n}$ denote the number of oxidants (4) and the number of reactant (VOC and $\mathrm{CO})$ species $(61),\left[\mathrm{OX}_{\mathrm{i}}\right]$ is the concentration of oxidant $\mathrm{i}$

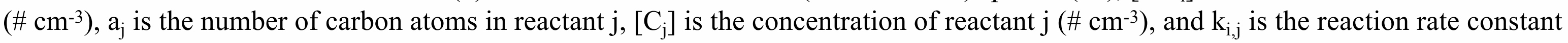
of oxidant $i$ and reactant $j\left(\mathrm{~cm}^{3} \#^{-1} \mathrm{~s}^{-1}\right)$. 